\title{
DEPTH THEOLOGY AND DEPTH ISLAM: Abraham Joshua Heschel and Nurcholish Madjid on Religious Pluralism
}

\author{
Media Zainul Bahri \\ Syarif Hidayatullah State Islamic University of Jakarta. \\ Email:
}

\begin{abstract}
The work attempts to elucidate the idea of religious pluralism of two very important figures in the traditions of Judaism and Islam: Abraham Joshua Heschel (1907-1972) and Nurcholish Madjid (1939-2005). Both figures are interesting to compare for some very important reasons. Although somewhat different, there is much in common between the two, especially in terms of their arguments on the issue of religious pluralism. Their ideas of religious pluralism are based on what the so-called "Depth Theology" (DT) and "Depth Islam" (DI). DT and DI are different from the usual theological dogmas that contain concepts and structures. DT and DI are not literal and superficial forms of religion. Their religious understanding went beyond the literal texts to look for the principles and spirit of religion in appreciating humanity, diversity and peace. In the context of inter-religious tensions due to suspicion, hatred, and hostility, the depth-theology of Heschel and the depth Islam of Madjid find their significance.
\end{abstract}

Keywords: depth; theology; religious; pluralism, interfaith; dialogue; Jewish, Indonesian; Islam.

\section{INTRODUCTION}

This article describes the idea of religious pluralism of two very important figures in the traditions of Judaism and Islam. Abraham Joshua Heschel (1907-1972) was a prominent Jewish rabbi and a highly respected professor of Judaism in America, while Nurcholish Madjid (1939-2005) was the prominent Indonesian Muslim scholar and a highly respected professor of Islamic studies. Since 1970s Madjid was well-known as the locomotive of Islamic thought renewal in Indonesia. As one of the neo-modernist Indonesian Muslim thinkers, Madjid plays an important and great role in the formation of Islamic thought within the Indonesian context, especially in the matters of religious and cultural pluralism. Both figures are interesting to compare because although somewhat different, there is much in common. They are 
both religious leaders and professors in their respective fields and were raised in an environment of strong traditionalism. Heschel was born and grew up in the Hasidic tradition and was connected to leading Jewish rabbis of the midcentury, and even with the Prophet (King) David. Madjid on the other hand was born and grew up in a traditional environment Nahdlatul Ulama (NU) in Jombang, East-Java. Abdul Madjid, the father of Madjid, was a favorite disciple of Hasyim Asy'ari, the founder of NU, and had been a son-in law of Hasyim Asy'ari. Although the two remained grounded in the roots of their traditions, both surpassed their own traditional bases.

From the Hasidic tradition, Heschel became a liberal thinker and pluralist. Heschel did some study of Islam, the Prophet Muhammad's history, Arabic language and culture, and got along well with Henry Corbin, a leading Islamic expert from France. ${ }^{1}$ While Madjid was an expert scholar in traditional and modern Islamic studies at once. Islamic formulation of Madjid which combines the modern Islamic discourses with the traditional Islamic literatures makes some observers such as Greg Barton² calls Madjid as "neo modernist Muslim" along with Fazlur Rahman. Aside from being thinkers and prolific writers, both Heschel and Madjid were humanitarian activists in a real sense.

\section{HESCHEL AND HIS TOUGHT OF GOD IN SEARCH OF MAN}

I am sure that Majid's biography is well known in Indonesian Islamic studies. At least, there are three representative works that trace all of Majid's life: Gagasan Islam Liberal di Indonesia by Barton (1999), Api Islam Nurcholish Madjid, Jalan Hidup Seorang Visioner by Ahmad Gaus (2010) and Cak Nur Sang Guru Bangsa: Biografi Nurcholish Madjid by Wahyuni Nafis (2014). Therefore, I would not to describe anymore the life story of Majid. On the contrary, Heschel may not be well known to Indonesian readers. So let me briefly describe the history of his life. His family lineage confirms the Orthodox Jewish environment and tradition that he was raised in. Abraham Joshua Heschel was born December 11, 1907, as the youngest child of Rabbi Mosche Mordecai Heschel of Pelzovizna and Rivka Reizel (Rebecca) Perlow Heschel.

${ }^{1}$ Seth Ward, "Islam, Muhammad, and Muslim-Jewish interaction in Heschel's writing," in Stanislaw Krajewski, ed., Abraham Joshua Heschel, Philosophy, Theology and Interreligious Dialogue (Wisbaden, Germany: Harroassowitz Verlag, 2009), p. 209. See also Paul B. Fenton, "Henry Corbin and Abraham Heschel," in Krajewski, ed., Abraham Joshua Heschel, Philosophy, Theology and Interreligious Dialogue, pp. 102-111.

${ }^{2}$ See dissertation of Barton, A Textual Study Examining the Writings of Nurcholish Madjid, Djohan Effendi, Ahmad Wahib and Abdurrahman Wahid 1968-1980 (Monash University Australia, 1998). This dissertation has been published in Bahasa by Paramadina Foundation, Gagasan Islam Liberal di Indonesia: Pemikiran Neo-Modernisme Nurcholish Madjid, Djohan Effendi, Ahmad Wahib dan Abdurrahman Wahid 1968-1980 (Jakarta: Yayasan Wakaf Paramadina, 1999). 
His parents were both descendants of very prominent rabbinic dynasties, whose origins reach back into the $15^{\text {th }}$ century. From his father's side, the most prominent of Heschel's ancestors include: Rabbi Dov from Mezritch (d. 1772), the first pupil and successor of Baal Shem Tov (d. 1760), founder of Hasidism; Rabbi Abraham Joshua Heschel, also known as "Apter Rav" (d. 1825), from whom Jewish philosophers took his given names and surname; Rabbi Israel Friedman from Ruzhin (d. 1850), recognized as a prince of Hasidism. On his mother's side, his ancestors include: Rabbi Pinchs from Koretz (d. 1791) and Rabbi Levi Yitzhak from Berdichev (d. 1809). ${ }^{3}$

Heschel was born in Warsaw, Poland, a metropolis where Jewishness flourished in many forms. Warsaw was the center of Congress Poland, which from 1815 to 1915 belonged to the Russian Empire, though it enjoyed the fullest autonomy of any province controlled by the Tsarist regime. Its Jewish community steadily increased to become the largest and most significant in Europe. By 1917, when Heschel was ten years old, Jews comprised 41 percent of Warsaw's population, fostering a vigorous diversity of religious and secular groupings. Heschel's Hasidic family was among the most traditional. Over the years, thousands of Jewish refugees had entered Warsaw, some maintaining their religious way of life, others bringing worldly trends and radical fervor. In Warsaw, Hasidism ${ }^{4}$ made up the largest grouping among observant Jews. In 1880 they composed two-thirds of the three hundred officially sanctioned synagogues, and many small shtibls (house of prayer and study); a short time later mitnagdim (opponents-traditional Jews suspicious of what they considered to be Hasidic overemphasis on prayer and ecstasy) arrived in droves from various parts of Eastern Europe. ${ }^{5}$ It is important to note that Heschel's surrounding environment was in crisis by the time he reached adolescence. This particular condition, which the Jewish community was

${ }^{3}$ Waldemar Szczerbinski, "Poland and Chistianity in Heschel's Life and Thought", in Krajewski (ed.) Abraham Joshua Heschel, Philosophy, Theology and Interreligious Dialogue, p. 11.

${ }^{4}$ Hasidic Judaism or Hasidism meaning "piety" (or "loving-kindness"), is a branch of Orthodox Judaism that promotes spirituality through the popularization and internalization of Jewish mysticism as the fundamental aspect of the faith. It was founded in 18th-century Eastern Europe by Rabbi Israel Baal Shem Tov as a reaction against overly legalistic Judaism. Baal Shem Tov is a great-great grandfather of Abraham Joshua Heschel. Hasidic teachings cherished the sincerity and concealed holiness of the unlettered common folk, and their equality with the scholarly elite. The emphasis on the Immanent Divine presence in everything gave new value to prayer and deeds of kindness, alongside rabbinical supremacy of study, and replaced historical mystical (kabbalistic) and ethical (musar) asceticism and admonishment with Simcha, encouragement, and daily fervour. This populist emotional revival accompanied the elite ideal of nullification to paradoxical Divine Panentheism, through intellectual articulation of inner dimensions of mystical thought.

${ }^{5}$ Edward Kaplan \& Samuel Dresner, Abraham Joshua Heschel, Prophetic Witness (USA: Yale University Press, 1998), p. 2. 
facing at that period of time in Warsaw, was not favorable as it was unstable due to the occurring world war.

Closer to actual memory, Heschel's grandfather, also named Abraham Joshua Heschel (1832-1881), sustained the dynasty. He established his family in Medzibozh, where he became Rabbi. Heschel's father, Rabbi Moshe Mordecai (1873-1916) was born there, as were his uncles and aunts. ${ }^{6}$ This establishment of the archetype rabbinic family was vital for the continuation of the Hasidic tradition to the next generation. Despite the fact that the Jewish community was disintegrating by the time Heschel reached adolescence, the establishment in Medzibozh by his grandfather had influenced him to maintain the tradition of his ancestors.

Mordecai then married Rivka Rezel Perlow Heschel ${ }^{7}$ (1874-1942), a daughter of Rabbi Jacob Perlow (1847-1902), another Hasidic master. Although born in Poland, Rabbi Perlow was brought up in the home of his maternal grandfather, Shlomo Hayim of Koidanov (1797-1862), a great Lithuanian Rabbi. At age fifteen, Heschel grandfather, i.e. Perlow, married a descendant of Rabbi Levi Yithzak of Berditchev, a mystic, Talmudic scholar and lover of humanity, who upheld compassion for suffering Jews even against God's strict judgment. ${ }^{8}$ Heschel's maternal side of ancestry had influenced his spiritual view and customs, which was considered liberal or unorthodox according to conventional Jewish tradition.

To sum up, after having finished secondary school in June 1927, the young Heschel desired to continue his academic studies. That autumn he left Poland and went to Berlin, which he believed to be the intellectual and cultural center of Europe. Heschel passed his oral doctoral exam on February 23, 1933; three weeks after Hitler came to power. Unfortunately, he met with great disadvantages in publishing his work, which was an official requirement for receiving the title of doctor in philosophy, due to officially sanctioned anti-Semitism in Germany. ${ }^{9}$ But it was only three years later (1936), due to exclusion of Jews from the German educational system, that the University of Berlin finally granted Heschel the title of doctor. ${ }^{10}$ In March 1939, Heschel received an invitation to the United States, where he was supposed to start

${ }^{6}$ Kaplan \& Dresner, Abraham Joshua Heschel, p. 6.

${ }^{7}$ Through an intricate genealogy, Heschel's paternal ancestor married to Heschel's maternal ancestors; hence his ancestral mother also has the name "Heschel" behind their names. Eventually Heschel mother, Rivka Reizel Perlow, also has the name "Heschel” behind her name.

${ }^{8}$ Kaplan \&Dresner, Abraham Joshua Heschel, pp. 6-10.

${ }^{9}$ Szczerbinski, "Poland and Chistianity in Heschel's Life", pp. 12-13.

${ }^{10}$ Paul B. Fenton, "Henry Corbin and Abraham Heschel" in Krajewski (ed.) Abraham Joshua Heschel, Philosophy, Theology and Interreligious Dialogue, p. 106. 
working in a Jewish high school. ${ }^{11}$ In March 1940, Heschel started to serve in the United States for five years as an Associate Professor of Philosophy and Rabbinic at the Hebrew Union College (HUC), the main seminary of Reform Judaism, in Cincinnati. In 1945, he held the title of Professor of Jewish Ethics and Mysticism and joined the faculty of the Jewish Theological Seminary of America (JTS) in New York. There he influenced a significant number of rabbis and educators in the Conservative movement of American Jewry up to the time of his death. On December 18, 1972, Heschel's completed manuscript of his last book, A Passion for Truth, on the Kotzker Rebbe and Kierkegaard was handed to his publisher before he passed away at his home in New York five days later. ${ }^{12}$

Heschel was a witness of Nazi brutality. He was able to survive all hardships, although he experienced enormous suffering. However, his mother and sister, Gittel were murdered: mother in Warsaw, sister in Treblinka. Another sister, Devorah died in the Nazi concentration camp Auschwitz. Another sister of Heschel, Esther, was slain during a bombing raid. For him, Poland became a place of burial and destruction of everything he appreciated and loved. This is probably why, despite longing to do so, he never returned. In one of his books he wrote: "If I went to Poland or Germany, every stone, every tree would remind me of contempt, hatred, murder, of children killed, of mothers burned alive, of human beings asphyxiated". ${ }^{13}$ It was truly a horrific memory for him. Personal suffering was an ennobling factor in Heschel's case. Instead of turning into a bitter person, he became a person full of empathy and care for other people overwhelmed by distress. ${ }^{14}$

As a theologian and Professor of Judaism, Heschel wrote significant books on Judaism and its relevance for modern man and interreligious dialogue. His works include The earth Is the Lord's (1941), Man Is Not Alone: A Philosophy of Religion (1951), The Sabbath: Its Meaning for Modern Man (1951), Man's Quest for God: Studies in Prayer and Symbolism (1954), God in Search of Man: A Philosophy of Judaism (1955), The Prophets (1962), Who Is Man? (1965), Israel: An Echo of Eternity (1969), A Passion of Truth (1973), Moral Grandeur and Spiritual Audacity (1996), and many others. Undoubtedly, Heschel was a mystic who loved God and man altogether. The fundamental issues in his books are not merely about a very close relationship between God and man, but also about love and empathy for human beings.

${ }^{11}$ Szczerbinski, "Poland and Chistianity in Heschel's Life", p. 13.

${ }^{12}$ Fritz A. Rothschild, "Introduction", in Abraham J. Heschel, Between God and Man, An Interpretation of Judaism, New York: Free Press Paperbacks, 1997, pp. 8-9.

${ }^{13}$ Szczerbinski, "Poland and Chistianity in Heschel's Life", p. 14. See Abraham J. Heschel, Israel: An Echo of Eternity, New York: Farrar, Straus and Giroux, 1968, p. 113.

${ }^{14}$ Szczerbinski, "Poland and Chistianity in Heschel's Life", p. 14. 
The first and foremost of Heschel's doctrine on theological-mystic is a theme on God in search of man. According to Heschel, most theories of religion start out with defining the religious situation as man's search for God and maintain the axiom that God is silent, hidden and unconcerned with man's search for Him. In adopting that axiom, the answer according to Heschel, is now given before the question is asked. To Biblical thinking, the definition is incomplete and the axiom false. The Bible speaks not only of man's search for God but also of God's search for man. "Thou dost hunt me like a lion", Exclaimed Job (10: 16), "From the very first Thou didst single out man and consider him worthy to stand in Thy presence". To Heschel, this is a mysterious paradox of Biblical faith: God is pursuing man. It is as if God were unwilling to be alone and had chosen man to serve Him. His will is involved in human yearnings. Heschel was convinced that all of human history as described in the Bible may be summarized in one phrase: God is in search of man. Faith in God is a response to God's question. ${ }^{15}$ When Adam and Eve hid from His presence, the Lord called: Where art thou? (Genesis 3: 9). For Heschel, it is a call that goes out again and again. It is a still small echo of a still smaller voice, not uttered in words, not conveyed in categories of the mind, but ineffable and mysterious, as ineffable and mysterious as the glory that fills the whole world. Religion consists of God's question and man's answer, which in Heschel's term: "The way to faith is the way of faith. The way to God is a way of God". For God is not always silent, and man not always blind. His glory fills the world. To Heschel, there are moments in which, to use a Talmudic phrase, heaven (God) and earth (man) kiss each other. ${ }^{16}$

It is clear now, according to Heschel that life is a partnership of God and man; God is not detached from or indifferent to human joys and grief. Authentic vital needs of man's body and soul are a divine concern. This is why human life is holy. God is a partner and a partisan in man's struggle for justice, peace and holiness, and it is because of His being in need of man that He entered a covenant with him for all time. Heschel emphasized that the essence of Judaism is the awareness of the reciprocity of God and man, of man's togetherness with Him who abides in eternal otherness. Hence for Heschel, there is only one way to define Jewish religion, "it is the awareness of God's interest in man, the

${ }^{15}$ Abraham Joshua Heschel, God In Search of Man: A Philosophy of Judaism (New York: Farrar, Straus and Giroux, 1983), p. 136. Heschel, Between God and Man, pp. 68-69.

${ }^{16}$ Heschel, God In Search of Man, pp. 137-38. Heschel, Between God and Man, pp. 69-70. In another chance, Heschel elucidated that the question "Where art thou?" Where is man? Is the first question that occurs in the Bible. For Heschel, it is man's alibi that is our problem. It is a man who hides, who flees, who has an alibi. God is less rare than we think; when we long for Him, His distance crumbles away. Edward Kaplan, Holiness In Word, Abraham Joshua Heschel's Poetics of Piety (New York: State University of New York Press, 1996), p. 126. 
awareness of a covenant,${ }^{17}$ of a responsibility that lies on Him as well as on us". Again for Heschel, God is now in need of man, because He freely made him a partner in His enterprise, a partner in the work of creation". In Heschel's words: "Every man is in need of God, because God is in need of man. Our need of Him is but an echo of His need of us". "18 "From the first day of creation the Holy One, blessed be He, longed to enter into partnership with the terrestrial world" to dwell with His creatures within the terrestrial world (Numbers Rabba, ch. 13.6; Genesis Rabbach. 3.9). Consequently, man's relationship to God is not one of passive reliance upon His Omnipotence but one of active assistance. ${ }^{19}$

Heschel's views on the high esteem of man can be seen also in his idea about the prophet figure. For Heschel, the prophet is a person par excellence whose existence has two sides: one is directed to man; the other is open to God. Moreover, his existence as a human being is determined by something which is outside knowledge and experience, which does not emanate from affections and moods, but emerges from the holy dimension of existence "the inner constitution of the universe, the system of divine values involved in every being and exposed to the activity of man". ${ }^{20}$ In other words, Heschel underlined that "I would say the prophet is a man who is able to hold God and man in one thought, at one time, at all times. This is so great and so marvelous, since it means that whatever I do to man, I do to God. When I hurt a human being, I injure God". ${ }^{21}$ And Heschel himself had learned from the prophet to be involved in the affairs of man, of suffering man. ${ }^{22}$ Thus, in Heschel's theology that the prophetic (and ultimately, Jewish) view of God is best understood not as anthropomorphic (that God takes human form) but rather as anthropopathic: that God has human feelings.

It is apparent that love of the fellow human being is a prominent theology of Heschel. In fact, Jewish tradition commands Jewish people to love all human beings because all are created in the image of God (tselem elohim). For Heschel, as for the great second century sage Rabbi Akiva, the supreme principle of

${ }^{17}$ The covenant sounds: "This day you have avowed the Lord to be your God, promising to walk in His ways, to obey His rules and commandments, and to hearken to His voice; And this day the Lord has avowed you to be His very own people, as He has promised you, and to obey His commandments" (Deuteronomy 26: 17.18).

${ }^{18}$ Heschel, Between God and Man, p.142.

${ }^{19}$ Heschel, Man Is Not Alone: A Philosophy of Religion (New York: Farrar, Straus and Giroux, 1979), pp. 242-43.

${ }^{20}$ Abraham J. Heschel, Moral Grandeur and Spiritual Audacity (New York: Farrar Straus Giroux, 1996), p. 322. See also Bernhard Dolna, "Keeping God and Man in one Thought", in Krajewski (ed.) Abraham Joshua Heschel, Philosophy, Theology and Interreligious Dialogue, p.125.

${ }^{21}$ Heschel, Moral Grandeur, p. 399. Dolna, “ Keeping God and Man”, p. 124.

${ }^{22}$ Heschel, Moral Grandeur, p. 399. Dolna, “ Keeping God and Man”, p. 129. 
the Torah is "love thy neighbor as thyself". According to Kasimow, one of Heschel's disciples, Heschel was very much in love with the Jewish tradition. He loved the Jewish people. But his greatness lies in his ability to extend this love to everyone, to see the humanity and touch of divinity present in various religious traditions. His love and compassion, for Kasimow, has brought great healing and great hope to all who have encountered him through the example of his life and the eloquence of his written word. ${ }^{23}$

\section{DEPTH THEOLOGY AND RELIGIOUS PLURALISM}

In general, most people know that Judaism is an exclusive religion. Christianity and Islam are missionary religions, but the Jewish people-on other hand-- do not intend non-Jewish to convert to their religion. So the question is: does Judaism have a theology of other religions? Alan Brill (2010) answers the question positively. Judaism has a wide range of texts that offer thoughts on other religions..$^{24}$ As is usual for Christian Theology, Brill then classifies Jewish theological categories into four major sections: exclusivism, inclusivism, pluralism, and universalism. First, Jewish exclusivism assumes that the sole domain of truth is the Torah and Judaism is the sole revealed religion. Due to God's revelations to the "chosen people", Jewish exclusivists merely acknowledge the merit of individual righteous gentiles, but do not acknowledge the collective virtues of other religious groups. For Jewish exclusivists, Judaism is the sole path to God; those who are not Jews follow a mistaken path and are at best bystanders in the divine scheme, at worst antagonists. ${ }^{25}$ However, exclusivism is not typical for Judaism, but occurs in any religious traditions.

Second, inclusivism affirms the uniqueness of Judaism, like the exclusivist, but rejects the idea that there is no value in other religions. ${ }^{26}$ Inclusivism sees other faiths as included within Jewish concepts, especially the concept of God as a philosophical monotheism. This theological monotheism allowed Jewish inclusivists to treat the first cause doctrine of the philosophers, the god of Plato and Aristotle, Christian Trinitarians, and all other people of faith as one essential unique God, even though, for inclusivists, these non-Jewish believers might have an incorrect view of the attributes of God. In addition, inclusivism can view other religions as derivations of the Jewish concepts of revelation,

\footnotetext{
${ }^{23}$ Harold Kasimow, "Heschel's View of Religious Diversity", in Krajewski (ed.) Abraham Joshua Heschel, Philosophy, Theology and Interreligious Dialogue, p. 201.

${ }^{24}$ Alan Brill, Judaism and Other Religions, Models of Understanding (New York, USA: Palgrave MacMillan, 2010), p. 1.

${ }^{25}$ Brill, Judaism And Other Religions, p. 151.

${ }^{26}$ Brill, Judaism And Other Religions, p. 17.
} 
ethics, or messianism. For inclusivists, the biblical knowledge of these ideas was spread through Christianity and Islam. ${ }^{27}$ Third, religious pluralism is a modern philosophic approach that accepts that one's religion is not the sole and exclusive source of truth. ${ }^{28}$ The pluralist recognizes that the great world religions have equally valid religious claims and addresses others in their own language ${ }^{29}$ Pluralism sees an impossibility of a universal truth available to all people, suggesting instead that each religion has limited access to truth. ${ }^{30}$

Fourth, universalism. This model divides into three parts: Theocentric, where God is a universal available to all humans in the minds or souls; Humanistic, where there is a common core of all humanity under God; Historic, where the divine has been fragmented among many nations. ${ }^{31}$ Over the centuries, many Jewish thinkers have embraced a universal approach in which the universalism of the prophets is joined with the philosophic monotheism of the middle Ages. They accept a universal truth available to all humanity beyond, but not against, revelation. In universal truth there is no need to refer to Judaism as the single truth; rather all knowledge is grounded in a higher divine knowledge. This approach, at times, blurs the line between religion and philosophy or between religion and ethics. However, for Brill, religious Universalists remain close to the inclusivists, in that everything is grounded in the teachings of Judaism. ${ }^{32}$

Now we will try to situate Heschel's theological views related to diversity of religions. No Religion Is an Island is probably Heschel's most important work and shows his comprehensive views on-let us say-"religious pluralism". Heschel starts with the belief that human beings have so much in common: a heart, a face, a voice, the presence of a soul, fears, hope, the ability to trust, a capacity for compassion and understanding, and sense of kinship for being human. This common background allows human beings to encounter each other. At the same time for Heschel, the human is also a disclosure of the divine, and all men are one in God's care for man. Many things on earth are precious, some are holy, but humanity is holy of holies. ${ }^{33}$ To meet a human being is an opportunity to sense the image of God, the presence of God. According to rabbinical interpretation, the Lord said to Moses: "Whenever you see the trace of man there I stand before you..." From this stand point, Heschel posed

${ }^{27}$ Brill, Judaism And Other Religions, p. 63.

${ }^{28}$ Brill, Judaism And Other Religions, p.129.

${ }^{29}$ Brill, Judaism And Other Religions, p.18.

${ }^{30}$ Brill, Judaism And Other Religions, p.129.

${ }^{31}$ Brill, Judaism And Other Religions, p. 23.

${ }^{32}$ Brill, Judaism And Other Religions, p. 99.

${ }^{33}$ Heschel, "No Religion Is An Island", in Harold Kasimow and Byron Sherwin (eds.) No Religion Is An Island: Abraham Joshua Heschel and Interreligious Dialogue (Eugene, Oregon: Wipf and Stock, 2008), p. 7. 
several critical questions: Does the difference in commitment destroy the kinship of being human? Does the fact that we differ in our conceptions of God cancel what we have in command? What divides us? What unites us? ${ }^{34}$ By expanding contemplation, Heschel came to an understanding that our conceptions of what ails us may be different, but the anxiety is the same. The language, the imagination, the concretization of our hopes is different, but the embarrassment is the same. We may disagree about the ways of achieving fear and trembling, but the fear and trembling are the same. The demands are different but the conscience is the same. The proclamations are different but the callousness is the same. Above all, while dogmas and forms of worship are divergent, but God is the same. ${ }^{35}$

Hence, facing religious diversities, Heschel is convinced that "In this aeon diversity of religions is the will of God." ${ }^{36}$ This, ontologically, is also the view of Muslim Sufis such as Ibn Arabī (1165-1240) and Rūmī (1207-1273) as well as Jewish and Christian mystics. Ibn 'Arabi for instance, believes that God is the root of all diversity of belifs within the cosmos. ${ }^{37}$ Like Heschel, Ibn 'Arabi does not see the diversity of religions and beliefs as a source of confusion or distress. Through the various differences, human beings can learn from and love each other. Another approach to religions can be found in Heschel's comments on the quotation from Prophet Malachi: "For from the rising of the sun to its setting My name is great among the nations, and in every place incense is offered to My name, and a pure offering: for My name is great among the nations, says the Lord of hosts (Mal. 1:11)”. For Heschel, this means that all those who worship their gods do not know it, but they are really "worshipping Me (God)" Though they confess different conceptions of God, are really worshipping One God, though they may not be aware of it. ${ }^{38}$ Again, this reminds us to what Ibn 'Arabì (d.believes when he comments on the verse, "Thy Lord hath decreed, that ye worship none save Him"(sūra al-Isrā: 23), he says, "that you should not worship others than Allah", but "Any things that you are worshiping, you are (actually) not worshiping other than Allah, as there is no other than Him in any existence that exist". 39

According to Heschel, the ultimate truth is not capable of being fully and adequately expressed in concepts and words. The ultimate truth is about the situation that pertains between God and man. "The Torah speaks in the language

${ }^{34}$ Heschel, "No Religion Is An Island", pp. 8-9.

${ }^{35}$ Heschel, "No Religion Is An Island", p. 9.

${ }^{36}$ Heschel, "No Religion Is An Island", p. 14.

${ }^{37}$ Ibn 'Arabī, al-Futūhāt al-Makkiyyah, Mahmūd Mațrajī ed. (Bairut: Dār al-Fikr, 2002), vol. VI, p. 303.

${ }^{38}$ Heschel, "No Religion Is An Island”, p.14.

${ }^{39}$ Ibn 'Arabī, Futūhāt, Vol. IV, p. 549. 
of man" said Heschel. For him, "Revelation is always an accommodation to the capacity of man". The voice of God reaches the spirit of man ina variety of ways, in a multiplicity of languages. ${ }^{40}$ From this fundamental views, Krajewski notes that one can claim that revelation had to be adjusted to the subjective capacity of each individual to understand, and to the relative cultures of the various nations. It cannot mean exclusive possession of absolute truth. ${ }^{41} \mathrm{Heschel}$ noted that "revelation is always an accommodation to the capacity of man," meaning that this is natural since religion is not revealed on an empty historical space. Religious teaching is nonetheless a response to the epochal condition and situation. In other words, revelation is not something that is outside the unchangeable and solid context, but it is inside the ever changeable context. Therefore, diverse race, nation, tribe and even different space and time require the distinction of religious teachings. Consequently, there are no single and universal teaching that can possibly be used for every epochal situation and condition.

If religious pluralism means "many ways to God", or "other religions are equally valid ways to the same truth" or "other religions speak of different but equally valid truth", it seems to be clear that Heschel confessed to the idea of religious pluralism; encompassing many religions on a seemingly equal basis when he concluded that: "One truth comes to expression in many ways of understanding".42 Another one of Heschel's ideas dealing with religious pluralism-or at least inclusivism-- can be seen also in his views on holiness and the holy man (saint). For Heschel, holiness is not the monopoly of any particular religion or tradition. Wherever a deed is done in accord with the will of God, wherever a thought of man is directed toward Him, the holy exists. The Jews do not maintain that the way of the Torah is the only way of serving God. Heschel then quoted a verse that reinforces his belief: "Let all the peoples walk each one in the name of its god, but we will walk in the name of the Lord our God forever and ever" (Mic. 4:5). ${ }^{43}$ Similarly, for Heschel, saints do not derive their saintliness from their ancestry. They become saints because they dedicate themselves to God and love Him, then God loves them, no matter of what religious tradition they belong to it. The highest degree to sainthood are the prophets who offer salvation. For Heschel, Christianity by Jesus and Islam by Muhammad are regarded as part of God's design for the redemption of all

${ }^{40}$ Heschel, "No Religion Is An Island”, p. 15.

${ }^{41}$ Stanislaw Krajewski, "Abraham J. Heschel and the Challenge of Interreligious Dialogue”, in Krajewski, (ed.) Abraham Joshua Heschel, p.173.

${ }^{42}$ Heschel, "No Religion Is An Island”, 15. Krajewski, "Abraham J. Heschel and the Challenge of Interreligious Dialogue", p.174.

${ }^{43}$ Heschel, "No Religion Is An Island", p. 19. 
men. ${ }^{44}$ This Heschel's view means that truth, wisdom and salvation do not belong to only one religion exclusively.

Heschel then quoted Rabbi Johanan Ha-Sandelar, a disciple of Rabbi Akiva, who says that "every community which is established for the sake of heaven will in the end endure; but one which is not for the sake of heaven will not endure in the end". And for Rabbi Jacob Emden, according to Heschel, Christianity and Islam are in the category of "a community which is for the sake of heaven and which will in the end endure" ${ }^{45}$ Heschel's idea of religious pluralism is indeed based on what he calls "Depth Theology" According to Kaplan, a scholar and expert on Heschel, depth theology assumes a firm distinction between dogma and an experiential, intuitive awareness of the living God. For Kaplan, Heschel's main point is that excessive dependence on concepts of God can undermine authentic religion. As corollary to this intellectualization of God as idea, Heschel warned against the danger of fundamentalism and literal-mindedness; he described dogma as "a poor man's share in the divine. A creed is almost all a poor man has. Skin for skin, he will give his life for all that he has. He may be ready to take other people's lives, if they refuse to share his tenets" ${ }^{46}$

According to Kaplan, depth theology, on the contrary, seeks common ground. Heschel uses analogies with art to explain why pre-theological intuition can favor connections between people who hold different beliefs: "Theology is like sculpture, depth theology like music. Theology is in the books; depth theology is in the hearts. The former is doctrine, the later an event. Theologies divide us; depth theology unites us". That is why, according to Kaplan, Heschel emphasizes the "cognitive emotions" of embarrassment, indebtedness, a sense of mystery and wonder-all of which can foster sensitivity to the divine. ${ }^{47}$ In the light of depth theology, Heschel always emphasized God as a Personal God who transcends all. For Heschel, believers should focus on God. God and religion are not identical. God is perfect; religion, by its very definition, is not. To equate religion and God is idolatry. Hence, in Hecshel's term, religion is a means not the end. Religion is a process of becoming; a perpetual process. It becomes idolatrous when religion is regarded as an end in itself. ${ }^{48}$

\footnotetext{
${ }^{44}$ Heschel, "No Religion Is An Island", pp. 20-21.

${ }^{45}$ Heschel, "No Religion Is An Island”, p. 21.

${ }^{46}$ Edward Kaplan, "Seeking God's Will Together": Heschel's Depth Theology as Commond Ground," in Krajewski (ed.) Abraham Joshua Heschel, p. 190.

${ }^{47}$ Kaplan, "Seeking God's Will Together", p. 190. See also Heschel, Man Is Not Alone: A Philosophy of Religion, New York: Farrar, Straus and Giroux, 1979, p. 265.

${ }^{48}$ Heschel, "No Religion Is An Island", 13. See also Krajewski, "Abraham J. Heschel and the Challenge of Interreligious Dialogue", p.180, and Alon Goshen-Gottstein, "Heschel and Interreligious Dialogue: Formulating the Questions", in Krajewski (ed.) Abraham Joshua Heschel, p. 163.
} 
However for Kaplan, depth theology does carry a radical theological consequence, i.e. religious pluralism and acceptance of the plausibility of other revelations. This, as Heschel asserted in a speech: "In this aeon, diversity of religions is the will of God". By citing Judah Halevi and Maimonides, and quoting a Talmudic source, he demonstrated that traditional Judaism was essentially pluralistic: "The ancient Rabbis proclaim: Pious men of all nations share in the life to come" ${ }^{49}$ Thus, the pluralist trusts that if God is God, God is the God of all peoples. And peoples share His Names and Mercy. Heschel's religious views which tend to be liberal, in the sense that it went beyond the conservative Jewish tradition show clearly that he was a pluralist. He was probably an epistemological and a mystical pluralist. However, it could also be understood that Heschel was an inclusivist because he often emphasized the grandeur of Jewish tradition and assumed that Judaism is the fundamental roots of Christianity and Islam. Heschel for instance, asserted that the Hebrew Bible is "the only book in the whole world that can never be replaced" ${ }^{50}$ Concerning the greatness and perfection of the Jewish Holy Book, Heschel presented a brief discussion between a Protestant pastor and Frederick the Great. The pastor, Christian Furchtegott Gellert, was asked by Frederick the Great, "Herr Professor, give me proof of the Bible, but briefly, for I have little time." Gellert answered, "Your Majesty, the Jews" ${ }^{51}$

However, there are also other views on Heschel. Harold Kasimow for instance, sees Heschel neither as a pluralist nor an inclusivist although he espouses a unique view of religious diversity. For Kasimow, Heschel is a Jewish interreligious artist who transcends the categories created by Christian scholars (exclusivism, inclusivism and pluralism). Heschel was a committed Jew, who, on the one hand, was able to affirm and live out the consequences of the fact that no religion has a monopoly on truth or holiness, and on the other hand, he was faithful to the Jewish religion and regarded it as the marvelous path to God..$^{52}$ Regardless of these views, one must underline that pluralism is not relativism or syncretism. A true pluralist is someone who loves God, is faithful to one's faith and religion, but at the same time acknowledges truth, holiness and salvation in other religions. And this is what Heschel stands for.

\section{NURCHOLISH MADJID ON RELIGIOUS PLURALISM}

As well as Heschel who bases his religious views on Jewish theology, Madjid also refers to Islamic theology. Theologically, Madjid idea of religious pluralism

\footnotetext{
${ }^{49}$ Kaplan, “Seeking God's Will Together”, p. 193.

${ }^{50} \mathrm{Heschel}$, God In Search of Man, p. 240.

${ }^{51}$ Heschel, "No Religion Is An Island", p. 17.

${ }^{52}$ Kasimow, "Heschel's View of Religious Diversity”, p. 201.
} 
begins from his insight about the concept of Tawhid, Islam and Kalimah Sawa ' (common words) among religions. He thought that monotheism (believe in one God) is the core doctrine of the prophets. The most important of Tawhid is full submission only to Allah, the only One God. This al-Isläm (submission) is the essence of all true religions..$^{53}$ Madjid concluded that "Behold, the only true religion in the sight of God is man's self-surrender unto Him (al-Isläm)". Here is the true interpretation of surah Āli 'Imrān verse 19, "Inna al-Dìn 'Inda Allāh al-Islām". In any religious tradition, totally surrender to God is the true and an authentic religiosity. The assertion of God in Āli Imrān 19 is accompanied by the further consequence that anyone who embraces to a religion other than al-Isläm and does not have the submission to God, then it is not genuine because it will be rejected, even if he is a "formal Muslim" or "Muslim" in a sociological sense. ${ }^{54}$

Therefore, according to Madjid, the al-isläm should be interpreted as a quality attitude, the total submission to God. Thus, before Islam to be a "proper name" or "historical religion" of Prophet Muhammad, that quality attitude and the Tawhid doctrine have been the main teachings of all the messengers of God. In its prevalent meaning, there was substantial relationship among the prophets. Madjid stated that there is only One Religion, namely al-Islām, but its law are varies as the Prophet Muhammad said, "Verily we are group of prophets, our religions are one," and "the prophets are brothers, one father with different mothers" ${ }^{55}$ By Al-Islām and Tawhid as main teachings emanating from Allah, then there is the unity of Truth, i.e., Universal Truth for all the God's messengers and mankind. According to Madjid, the Universal Truth is one although its manifestation is varies. In other words, the Universal Truth which can also be referred to the "Universal Religion", or the "Straight Religion", or the "True Religion", is the only One exists because it is originates from The Only One (God). However when it comes down to historical world or phenomenon realm, it manifests into different religions and beliefs. To Madjid, the fact of the "essential unity" of religions and beliefs is not surprising because all of truth originates from the Same Source, al Haqq. All the prophets brought the teachings of the same truth. ${ }^{56}$

Dealing with the concept of substantial relationship among the prophets,

${ }^{53}$ Nurcholish Madjid, Islam, Doktrin Dan Peradaban: Sebuah Telaah Kritis tentang Masalah Keimanan, Kemanusiaan, dan Kemodernan (Jakarta: Yayasan Wakaf Paramadina, 1992), p.181.

${ }^{54}$ Madjid, Islam, Doktrin Dan Peradaban, 182. Madjid, Islam Agama Kemanusiaan, Membangun Tradisi dan Visi Baru Islam Indonesia (Jakarta: Yayasan Wakaf Paramadina, 1995), pp. xii-xv.

${ }^{55}$ Madjid, Islam, Doktrin Dan Peradaban, p. 182.

${ }^{56}$ Madjid, Islam Agama Kemanusiaan, pp. 138-139. 
Madjid then discussed about People of the Book or Ahl al-Kitāb. According to Madjid, Islamic concept on Ahl al-Kitāb is a unique which never existed before Islam. Islam through Ahl al-Kitäb confers certain acknowledgement to other religions that have holy books. This concept has a tremendous impact on religious and socio-cultural of mankind. Accordingly, Madjid said that Islam is the first religion introducing tolerance and religious freedom. The doctrine of Ahl al-Kitāb encouraged Muslims in their history to developed cosmopolitanism based on social order, inclusive and tolerant society. ${ }^{57}$ Mostly, Islamic discussion on Ahl al-Kitāb is usually addressed to the Jews and Christians as the Qur'an explicitly mentioned about. Yet, for Madjid it is reasonable that the Quran only mentioned the two because the Arabs, in general, and the first Muslims recognized them as the communities who have holy books. Besides, they do not know other communities. By referring to The Holy Quran, Translation and Commentary of Abdullah Yusuf Ali, Tafsir alManār of Muhammad Rasyid Ridha and al-Mu'inn al-Mubīn of Abdul Hamid Hakim, a Muslim scholar of Nusantara, Madjid invites Muslims to take into consideration that believers of other religions such as the Sabeans, Majusi, Zoroastrians, Hindus, Buddhists, Confucians, Shintoists, Taoists and others who have the holy books also deserves to be called Ahl al-Kitäb. ${ }^{58}$

For Madjid, there are three fundamental reasons: first, there are verses of the Qur'an asserted that "Every community has had an apostle", 59 "...some of them (apostles) We have mentioned to you, and some of them We have not mentioned to you", ${ }^{60}$ another verse stated that "And never have We sent forth any apostle otherwise than (with a message) in his own people's tongue". ${ }^{6}$ Therefore, according to Madjid, the so-called ummah is a group of people. Hence, if there is community in Java, then surely there is a messenger. As well as other places like in China, India or Persia, God must has sent down His messenger to bring glad tidings and admonitions and some principal teachings. ${ }^{62}$ Second, by quoting Rashid Ridha, Madjid argued that the Quran only mentioned the Jews, Christians, Sabeans, and Zoroastrians because

${ }^{57}$ Madjid, Islam Agama Peradaban, Membangun Makna dan Relevansi Doktrin Islam Dalam Sejarah (Jakarta: Yayasan Wakaf Paramadina, 1995), pp. 69-70.

${ }^{58}$ Madjid, Islam Agama Kemanusiaan, p. 103. See Madjid, Islam, Doktrin Dan Peradaban, p. lxxix.

${ }^{59}$ Muhammad Asad, The Message of the Quran (Gibraltar: Dar al-Andalus, 1980), p. 298.

${ }^{60}$ Asad, The Message of the Quran, p. 727.

${ }^{61}$ Asad, The Message of the Quran, p. 370.

${ }^{62}$ Madjid, "Pengantar", in Komaruddin Hidayat and Ahmad Gaus, Passing Over, Melintasi Batas Agama (Jakarta: Gramedia Pustaka Utama, 1999), second edition, pp. xxxiixxxiii. Madjid, "Dialog Di Antara Ahli Kitab (Ahl Al-Kitab): Sebuah Pengantar", in George B. Grose \& Benjamin Hubbard (eds.), Tiga Agama Satu Tuhan, trans. Santi Indra Astuti (Bandung: Mizan, 1998), pp. xxii-xxiii. 
these communities were the first recognized by the Arabs and geographically, they were close to the Arabs. If the Quran named Hindus, Buddhists, Taoist, and Confucians who were not recognized by the Arabs then it would have been something "peculiar and extraneous (ighrāb)" to them. ${ }^{63}$ Third, by quoting Abdul Hamid Hakim, Madjid agreed that the believers of Hinduism, Buddhism, Confusionism, and Shintoism were included as Ahl al-Kitāb because their genuine teaching was Tawhid. ${ }^{64}$

Acknowledging Ahl al-Kitāb as community who also profess Tawhid, Madjid then discussed about salvation. The classical matter that has and will always be a sharp controversial in Muslim scholars is shall non-Muslims get the God's Mercy and salvation in the hereafter? Madjid gone upon al-Baqarah verse 62 which stated that "those who have attained to faith (in this divine writ), as well as those who follow the Jewish faith, and the Christians, and the Sabeans all who believe in God and the Last Day and do righteous deeds-shall have their reward with their Sustainer, and no fear need they have, and neither shall they grieve". ${ }^{65}$ Based on this verse, Madjid promoted the interpretations of Abdullah Yusuf Ali and Muhammad Asad who asserted that the God's word is a certainty; anyone of any religious traditions deserves of salvation as long as "he believes in God and the Last Day and do righteous deeds". For Madjid, This guarantee of salvation applies regardless whether he was descendant of Prophet Ibrahim (Abraham) like the Jews and the Quraisy in Mekkah or not. As God said to Ibrahim when He will make him a leader of men and then Ibrahim asked: "And (will you make leaders) of my offspring as well?" God answered, "My covenant does not embrace the evildoers". ${ }^{66}$ Thus, Madjid emphasized that salvation cannot be obtained by people due to heredity but for anyone who believes in God, the Day of judgment, and righteous action in life, a principle which is strongly emphasized in the Quran. ${ }^{67}$

By citing the two verses of al-Maidah: (65) "If the followers of the Bible would but attain to (true) faith and God-consciousness, We should indeed efface their (previous) bad deeds, and indeed bring them into gardens of bliss"; (66) and if they would but truly observe the Torah and the Gospel and all (the revelation) that has been bestowed from on high upon them by their Sustainer, they would indeed partake of all the blessings of heaven and earth. Some of them do pursue a right course; but as for most of them vile indeed is what they do", again Madjid asserted that it is obligatory for Muslims to defending the

${ }^{63}$ Madjid, Islam Agama Peradaban, pp. 82-83. Madjid, Islam Agama Kemanusiaan, pp. 94-95.

${ }^{64}$ Madjid, Islam, Doktrin Dan Peradaban, p. lxxix.

${ }^{65}$ Asad, The Message of the Quran, p.14.

${ }^{66}$ See Asad, The Message of the Quran, p. 26.

${ }^{67}$ Madjid, Islam, Doktrin Dan Peradaban, pp. 187-188. 
tradition of pluralism, tolerance and religious freedom. The salvation not only for Muslims who do right but also for the people of the book. ${ }^{68}$ The mentioned Islamic views earlier for Madjid show that Islam fundamentally is inclusive and its interpretation is more pluralist, ${ }^{69}$ and no doubt Madjid himself was an inclusivist, even a pluralist and universalist. According to Madjid, pluralism cannot be understood simply by saying that the people of Indonesia is a plural, diverse, consisting of various races and religions, which is actually only describe the impression of fragmentation, not pluralism. Pluralism should also not be understood merely as negative good, just seen its utility to keep fanaticism at bay. Pluralism must be interpreted as genuine engagement of diversities within the bonds of civility. Moreover, pluralism is a necessity for the salvation of mankind, through the result of supervision and balances. ${ }^{70}$

On many occasions, Madjid often refers to Spain Islam as a concrete example of religious pluralism within Muslim community. Spain Islam for Madjid brought out what the so- called "three religions and one bed room". By quoting Max Dimont, Madjid believes that "under the sub-sequent 500-year rule of the Muslims emerged the Spain of three religions and one bed room. Mohammedans, Christians, and Jews shared the same brilliant civilization" ${ }^{71}$ A very interesting fact that is recognized by Western scholars, for Madjid, is that one of the greatest blessings of Spain Islam is the enjoyment of religious freedom for Jews and their religious development, a pleasure that cannot be achieved by the Jews even in modern times. In this Spain Islam, Jewish people experienced their golden age. ${ }^{72}$ In Indonesian context, for Madjid, the whole explanation of Islam dealing with pluralism is actually represented by Pancasila as the philosophical basis for Indonesian pluralism, ${ }^{73}$ which also requires a genuine engagement of Indonesian diversities. After a long and exhausting dialogue among leaders of the nation from different religions, beliefs and ethnic groups, the birth of Pancasila was a blessing for Indonesian pluralism. Thus, Pancasila was a result of struggle of the plurality fact of Indonesia. With religious pluralism as practiced in Spain Islam and political pluralism in Pancasila's Indonesia, Madjid imagines Muslims have a high civilization and could enrich their religiousness due to appreciate religious and cultural diversities.

${ }^{68}$ Madjid, "Dialog Di Antara Ahli Kitab (Ahl Al-Kitâb): Sebuah Pengantar", p. xxvii.

${ }^{69}$ Madjid, "Dialog Di Antara Ahli Kitab (Ahl Al-Kitâb): Sebuah Pengantar", p. xix.

${ }^{70}$ Madjid, "Pluralisme Agama Di Indonesia," Ulumul Qur'an, Jurnal Ilmu dan Kebudayaan, Vol. VI, No. 3 (1995), pp. 63 \& 65. Madjid, Masyarakat Madani dan Investasi Demokrasi: Tantangan dan Kemungkinan, Republika August 10, p.1999.

${ }^{71}$ Madjid, Islam, Doktrin dan Peradaban, p. Ixxvii.

${ }^{72}$ Madjid, Islam, Doktrin dan Peradaban, p. xc.

${ }^{73}$ Madjid, "Pluralisme Agama Di Indonesia", p. 64. 


\section{SHARED INTERFAITH DIALOGUE BETWEEN JUDAISM AND ISLAM}

Heschel also formulated the importance of interfaith dialogue among religious traditions. As stated earlier, that the idea of religious pluralism in Heschel's depth theology is based on two main things. First, God and man mutually seek and need each other, their relationship both active and dynamic. This relationship especially from the position of human beings is based on a "deep faith" in God, not a "shallow faith". This for Heschel means that the first and most important prerequisite of interfaith is faith. Interfaith must come out of depth, not out of avoid or absence of faith. It is not an enterprise for those who are half-learned and spirituality immature. ${ }^{74}$ Thus, a mature faith is the basic requirement, before a person meets for interfaith dialogue with others. Superficial faith will only hurt him/her-self and their dialogue partners.

Second, for Heschel, inter-faith dialogue should be based on humility, mutual esteem and reverence. That means the full respect of the human being, regardless of their religion. Full appreciation will appear if someone has a "deep faith" or "depth theology" in Heschel's terms. Depth theology is different from the usual theological dogma that only contains concepts and structures. In the language of Heschel, "theology speaks for the people, while depth theology speaks for the individual. Depth theology seeks to meet the person in intimate moments in which the whole person is involved". In conjunction with the dialogue, Krajewski confirms the importance of depth theology, as the "theme of depth theology is the act of believing", the theme of the "depth theology" is the act of dialoguing, or rather Interreligious dialoguing. ${ }^{75}$

Heschel repeatedly stressed that depth of theology should give birth to respect for other people, not just to the physical, but also to their faith and commitment. He stated that "respect for each other's commitment, respect for each other's faith, is more than a political or social imperative. It is born of the insight that God is greater than religion, that faith is deeper than dogma, that theology has roots in depth theology". Heschel also underlined that the dialogue between faiths requires a person to be faithful to his or her historical religion. Important also to keep in mind is Heschel's warning that religion is not identical with God. Loyalty to religion means loyal to the values of divinity. For Heschel, "To equate religion and God is idolatry" ${ }^{76}$

Madjid was also actively concerned to encourage inter-faith dialogue. For him as a Muslim, the main base of the inter-religious dialogue according to

\footnotetext{
${ }^{74}$ Heschel, "No Religion Is An Island”, pp. 10-11.

${ }^{75}$ Krajewski, "Abraham J. Heschel”, pp. 179-180.

${ }^{76}$ Heschel, "No Religion Is An Island", p. 13.
} 
Islamic perspective is that the Quran itself--implicitly and explicitly--calls the believers to perform dialogue. Madjid theological ideas on interfaithdialogue are actually closely connected to the issue of religious inclusivism and pluralism he embraces. His main ideas can be explained in two important things; firstly, there is unity of the prophetic message. The prophets that were sent by God brought different teachings (sharia) as needed to the people and the contexts of each. Yet, the core of prophetic message is actually in the same spirit that is full submission to God namely al-isläm and Tawhid. The core of all the prophet's religions (Din) is same ${ }^{77}$ and their umma and religions are one, as God said, "Verily (O you who believe in $\mathrm{Me}$ ) this community of yours is one single community, since I am the Sustainer of you all, worship then me alone (al-Anbiyā: 92)" and "Verily, this community of yours is one single community, since I am the Sustainer of you all, remain then conscious of me (al-Mu 'minūn: 52)”.

Muslims are also commanded to believe (confess) to all the prophets without differentiating one over the others and surrender to God. Secondly, doctrine on Ahl al-Kitab which confers certain acknowledgement to other religions that have holy books and gives freedom to practice their religion respectively. For Madjid, these inclusive and pluralist Islam make inter-religious dialogues are something that is not only possible, but also necessary and required. Muslims are commanded by God to invite the leaders of People of the Book to the "common words (kalimat-un sawa' ')", which is headed to the teachings of the Only One God (Tawhid) as referred to süra Âli 'Imrān: 64. Those positive and sympathetic verses toward the People of the Book for Madjid, is a call of God to Muslims to open up the dialogue process in order to obtain a shared belief about the most profound Truth, as Wilfred Cantwell Smith called, "All inner faith is interfaith".78

Although the essence of all religions is one and same but historically, the sociocultural manifestations are different. There is even an exoteric doctrine that cannot be 'reconciled' among religions. Therefore, dialogue is indispensable for peace. According to Madjid, if some languages and verbal beliefs of religion are different, but the faiths in the social dimension of humanity are necessarily same. According to the Prophet, al-islam is best expressed in humanitarian activities such as helping the poor or work for peace without exception. By this view, Madjid actually was talking about two models of dialogue at the

${ }^{77}$ As stated in sūra al-Syūrā: 13, "In matters of faith, He has ordained for you that which He had enjoined upon Noah and into which We gave thee (O Muhammad) insight through revelation as well as that which We had enjoined upon Abraham, and Moses, and Jesus: Steadfastly uphold the (true) faith, and do not break up your unity therein".

${ }^{78}$ Madjid,"Dialog Di Antara Ahli Kitab", pp. xxvii-xxviii. 
same time: the dialogue at the level of theological and practical (ethical) that was on the concrete social problems of humanity. At these two levels, the religious communities in any religious traditions can actually learning and sharing within dialogue. For Madjid, by looking at those dynamic models of dialogue, then interreligious dialogue can be seen as the realization of the most fundamental religious teachings, and the cooperation of humanity based on faith in the Only One God means fulfilling glorious commands as stated in the Scripture.

According to Madjid, the aim in theological dialogue is not to 'create' a common ground or even uniformity, because it is like a "betray" in religious tradition. Every religion has its unique itself. Therefore, what one looks for is to get the common words (theologically) as far as possible, not the teachings that difficult to blend in. One has be able to classify between the theological-philosophical religious teachings and the others teachings in their historical dimensions. For Madjid, dialogue is 'apple to apple'. Things that are historically to be compared with the historical. Things that are normative should be compared with the normative. Dialogue should be equal and honest. A dialogue based on togetherness, justice, honesty, and openness will be enriched one each other. ${ }^{79}$ In full awareness, Madjid's ideas about religious pluralism, tolerance, and dialogue are rooted in the historical heritage of Islamic civilization that is inclusive and cosmopolitan, as well as Pancasila and the true diversity of the culture of Indonesian society. Moreover, as Heschel developed his depth theology, Madjid realized that he was also exploring the so-called "depth Islam". As I discussed in my article on the thought of Abdurrahman Wahid (2015), depth Islam is not a literal and superficial form of Islam. Depth Islam is an understanding that goes beyond the literal texts to look for the principles and spirit of Islam in appreciating humanity, diversity and peace. Depth Islam can also be referred to as "liberal Islam" or "substantial Islam", in terms of looking at the whole context of the text and beyond..$^{80}$

Inter-faith dialogue between Muslims and Jews has been carried out by several important figures, scholars, or journalists in several places on this earth. Kujawa Holbrook and Sheryl for example, in their article "Interfaith Dialogue in Practice: Christian, Muslim and Jew," reviewed that one of the interesting phenomena in inter-faith dialogue conducted in the Western world (by some leading scholars) is by using communication strategies rather than the usual specialists in theology or politics. By using communication strategy, Holbrook

${ }^{79}$ Madjid,"Dialog Di Antara Ahli Kitab", pp. xx-xxi.

${ }^{80}$ See Media Zainul Bahri, "Abdurrahman Wahid, Depth Islam, and Religious Pluralism", Ulumuna, Journal of Islamic Studies (Mataram State Islamic Institute, Vol. 19, No. 2, 2015 ), p. 321. 
viewed that individuals and groups engaged in processes that led to greater mutual understanding among those three religions. ${ }^{81}$ Similarly, there is one very interesting book written by Yossi Klein Halevi, a Jew, a correspondent for The New Republic and senior writer for The Jerusalem Report, entitled At The Entrance To The garden of Eden (2001). In his work, Yossi Halevi describes his unprecedented and extraordinary spiritual journey to discover, as a religious Israeli Jew, a common spiritual language with his Christian and Muslim neighbors in the Holy Land, Jerusalem. "Could religion be a source of unity?" wondered Halevi. To find the answer, he began a two-year exploration of the devotional life of Christianity and Islam. He followed their holiday cycles, befriended Christian monastics and Islamic mystics, and joined them in prayer in monasteries and mosques-searching for wisdom and holiness in places that are usually off-limits to outsiders of other faiths. ${ }^{82}$ The more dialogue and encounter among believers, the more positively for world peace.

\section{CONCLUSION}

Heschel and Madjid may have never met physically. There is no data or indication of encounters between them. Moreover, when Heschel died in 1972, Madjid was intensively spreading the ideas of secularization, modernization, and was rejecting Theocracy. In 1968-as a Chairman of the HMI-- Madjid was invited to the United State for a month and a half and met with activists, academicians, religious and political leaders, but was never mentioned Heschel. However, both had a great interest in the religion of others. Madjid was enthusiastic about Judaism and the Jewish perspective. In his writings on Islam, Madjid often discussed Jewish perspectives and did compare between Islam and Judaism. Heschel himself, in addition to studying the Semitic religions, including Islam from the Jewish scholar, Eugen Mittwoch, engaged several times in interfaith dialogue with Seyyed Hossein Nasr, and made friends with other Islamic scholars, such as Henry Corbin. ${ }^{83}$

Both figures are unique in the sense that they both challenge to break through the thick wall of exclusiveness and conservatism espoused largely by American-European Jews and the Muslims of Indonesia. The fact that Heschel hails from the nobility or very elite of his respective tradition and Madjid was an elite Indonesian Islam highly respected, has not made them take advantage of their high social status and live luxuriously. Instead, they use their position

\footnotetext{
${ }^{81}$ Kujawa Holbrook and Sheryl A., "Interfaith Dialogue in Practice: Christian, Muslim and Jew," Journal of Anglican Theological Review, Fall 2015, p. 1.

${ }^{82}$ See Yossi Klein Halevi, At The Entrance To The Garden of Eden (New York: HarperCollins, 2001).

${ }^{83}$ Seth Ward, "Implications of Abraham Joshua Heschel”, p. 209.
} 
to fight for equality, peace and justice to mankind. Both have dedicated their entire lives to those three things. Owing to that, they have a huge influence in their respective traditions. Heschel has contributed significantly to a more humane face of the American-European Jewish world, and the Christian world in the West. Dozens of books have been written about him and a series of international conferences have been held to commemorate his services. In his honor, some schools in the United States have been named "Heschel" such as in the Upper West Side of New York City, Northridge, California and Toronto, Canada. In 2009, a Missouri Highway was also inaugurated as the "Dr. Abraham Joshua Heschel Highway".

Madjid, as an Indonesian Muslim, has not only made a large contribution to give a face to inclusive Indonesian Islam, but has also become the face of Islamic Southeast Asia, where he is known and well-remembered by Islamic scholars of Malaysia, Singapore, Brunei, and the Philippines. In Indonesia alone, in addition to tens of books and articles written about Madjid, there have appeared thousands of young Muslims who are continuing to develop Madjid ideas of inclusive and pluralist Islam. The greatest legacy of Madjid is Paramadina University, a university that was established for the middle class Muslim Indonesia. Madjid had a dream that Indonesian Muslims are modern and welleducated but remain to embrace moderate and inclusive Islam. Madjid was a Rector of this University from 1998 to 2005. After his death in 2005, Madjid family and their sympathizers founded Nurcholish Madjid Society, a foundation spread the Islamic ideas of Madjid in building moderate Islamic intellectual thought, which encourages the creation of democracy, multiculturalism and tolerance among Muslims in Indonesia and around the world.

At college, Madjid was active in the Islamic student organization, where he held the very prestigious position of General Chairman of Indonesia's largest Islamic student organization, namely the Himpunan Mahasiswa Islam (HMI, Islamic Student Association) for two consecutive periods: 1966-1969 and 19691971. As well as scholar who integrates Islam with democracy and the modern world, Madjid has also been active in the commission of election monitoring (1995-1997). As a democrat in the authoritarian New Order regime, Madjid was often campaigning for what he calls "the loyal opposition". Dealing with fighting for freedom and human rights, he was also active as a member of the national commission for human rights (1993-1998). Madjid was also active as a central board of ICMI (Ikatan Cendekiawan Muslim Indonesia, Association of Indonesian Muslim Intellectuals) from 1990 to 1995. In the moments before the fall of New Order in 1998, President Suharto asked Madjid to become a

${ }^{84}$ http://en.wikipedia.org/wiki/Abraham Joshua Heschel, downloaded at 07-04-2013. 
Chairman of the Reform Committee, but Madjid rejected it. In a conversation with Suharto, Madjid stated that "what is understood by the people of the reform is that the President should resign" ${ }^{85}$ For his services, Madjid was later buried at the Heroes Cemetery (Taman Makam Pahlawan) in Jakarta.

As well as Madjid who devoted his life to Islam, Islamic Studies and humanity, Heschel also devoted much of his life to the study of Judaism, became an academician and professor of Judaism. He wrote many serious books about Judaism. Nevertheless, Heschel was not merely a scientist who systematically studied religion as an object. He was a devoted person, who was "fully engaged" with his Jewishness. He is considered by the Jewish community in America and Europe as a Jewish saint, some Jews even believe him to be a "prophet". Although, he would never be so bold as to consider him gifted with prophetic inspiration. Instead, Heschel humbly replied: "I do not want to accept this praise; because it is not for me to say that I am a descendant of the prophets. It is arrogant enough to claim, that I am a descendant of the prophets, what are called B'nai Nevi'im. So let us hope and pray that I am worthy of being a descendant of the prophets". ${ }^{86}$

Heschel was also heavily involved with significant humanitarian events. Kaplan said that in the early 1960s to the year of his death in 1972, Heschel emerged as a social activist-humanitarian. During that period, Heschel was involved in inter-religious dialogue with Protestant and Islam leaders, with cardinals and with the Pope himself. In 1965, together with his close friend, Martin Luther King Jr., he took to the streets demanding civil rights. Around 1967-1968, in the name of God and humanity, also with Luther King, he demonstrated on the street in refusal of the Vietnam War. ${ }^{87}$ Heschel called social-humanitarian activities as a form of prophetic radicalism. ${ }^{88}$ The world today has indeed faced many cases of conflict based on religious backgrounds. Hatred, hostility and religious wars are often born out of religious misunderstanding. In the context of inter-religious community tensions due to suspicion, hatred, and hostility, the depth-theology of Heschel and the depth Islam of Madjid find their significance.

${ }^{85}$ Ahmad Gaus, Api Islam Nurcholish Madjid, Jalan Hidup Seorang Visioner (Jakarta: Kompas, 2010), p. 220.

${ }^{86}$ Bernhard Dolna, "Keeping God and Man”, p. 130.

${ }^{87}$ According to Kaplan, the Vietnam emergency became the religious imperative of Heschel's final years of life. At a worship meeting in Washington DC in 1967, in which Kaplan himself participated, Heschel explained how the divine image brought him to oppose the war. He said: "The encounter of man and God is an encounter within the world. We meet within a situation of shared suffering, of shared responsibility... Though I am not a native of Vietnam, ignorant of its language and traditions, I am involved in the plight of the Vietnamese." Kaplan, Holiness in Words, p. 110.

${ }^{88}$ Kaplan, Holiness In Words, pp. 92-99. 


\section{BIBLIOGRAPHY}

Arabi, M. I., (2002). al-Futūhāt al-Makkiyyah, 8 volumes. Bairut: Dar al-Fikr.

Asad, M., (1980). The Message of the Quran. Gibraltar: Dar al-Andalus.

Bahri, M. Z., (2015). Abdurrahman Wahid, Depth Islam, and Religious Pluralism. in Ulumuna, Journal of Islamic Studies, Vol. 19, No. 2.

Brill, A., (2010). Judaism and Other Religions, Models of Understanding. New York, USA: Palgrave MacMillan.

Gaus, A., (2010). Api Islam Nurcholish Madjid, Jalan Hidup Seorang Visioner. Jakarta: Kompas.

Grose, G. B. \& Hubbard, B. (eds.). (1998). Tiga Agama Satu Tuhan (translated into Bahasa Indonesia by Santi Indra Astuti. Bandung: Mizan.

Halevi, Y. K. (2001). At The Entrance To The Garden of Eden. New York: HarperCollins.

Heschel, A. J., (1997). Between God and Man, An Interpretation of Judaism. New York: Free Press Paperbacks.

-------., (1983). God In Search of Man: A Philosophy of Judaism. New York: Farrar, Straus and Giroux.

., (1968). Israel: An Echo of Eternity. New York: Farrar, Straus and Giroux.

-------., (1979). Man Is Not Alone: A Philosophy of Religion. New York: Farrar, Straus and Giroux.

-------.., (1996). Moral Grandeur and Spiritual Audacity. New York: Farrar Straus Giroux.

Hidayat, K. and Gaus, A., (1999). Passing Over, Melintasi Batas Agama. Jakarta: Gramedia Pustaka Utama.

Kujawa, H. \& Kujawa, A. S., (Fall 2015). Interfaith Dialogue in Practice: Christian, Muslim and Jew. in Journal of Anglican Theological Review.

Kaplan, E. \& Dresner, S., (1998). Abraham Joshua Heschel, Prophetic Witness. USA: Yale University Press.

Kaplan, E., (1996). Holiness In Word, Abraham Joshua Heschel's Poetics of Piety. New York: State University of New York Press.

Kasimow, H. and Sherwin, B. (eds.)., (2008). No Religion Is An Island: Abraham Joshua Heschel and Interreligious Dialogue. Eugene, Oregon: 
Wipf and Stock.

Krajewsky, S. (ed.)., (2009). Abraham Joshua Heschel, Philosophy, Theology and Interreligious Dialogue. Wisbaden, Germany: Harroassowitz Verlag.

Madjid, N., (1992). Islam, Doktrin Dan Peradaban: Sebuah Telaah Kritis tentang Masalah Keimanan, Kemanusiaan, dan Kemodernan. Jakarta: Yayasan Wakaf Paramadina.

., (1995). Islam Agama Kemanusiaan, Membangun Tradisi dan Visi Baru Islam Indonesia. Jakarta: Yayasan Wakaf Paramadina.

-------., (1995). Islam Agama Peradaban, Membangun Makna dan Relevansi Doktrin Islam Dalam Sejarah. Jakarta: Yayasan Wakaf Paramadina. 
